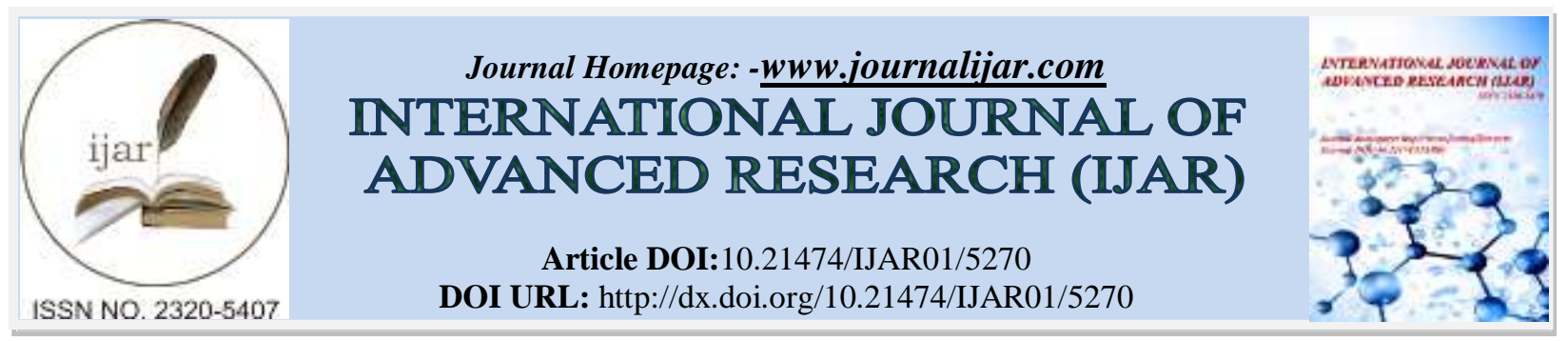

RESEARCH ARTICLE

\title{
MANAGEMEN OF OVARIN ENDOMETRIOMA (KAPHAJA GRANTHI) BY PRINCIPLE OF AYURVEDA: CASE STUDY.
}

Dr. Hem Prakash.

\section{Manuscript Info}

(..........................

Manuscript History

Received: 24 June 2017

Final Accepted: 26 July 2017

Published: August 2017

Key words:-

Granthi, Endometrioma,Tridosa.

\section{Abstract}

Ovarian endometrioma is a benign estrogen dependent cystic mass arising from ectopic endometrial tissue within the ovary. It contains thick ,brown ,tar like fliud, which may be reffered to as a chocolate cyst. This can be correlate as kaphajagranthi in ovary. It can be cause of infertility in women.

Ayurvedic literature defines three body control system (dosas) vizvatta pitta kapha, which mutually coordinate to perform the normal functions of the body. Granthi (cyst) formation is a condition of tridosa( vatta ,pitta ,kapha) vittition origin. Ovarian endometriomaresemblance kaphajagranthi due to its charectristics. This case is an ideal example of ovarian endometrioma, and is successfully treated with Ayurvedic drugs. Patient was suffering with whole abdominal pain, burning micturation whitish discharge, loss of appetite, mild itching in lower abdomen, constipation and weakness. Patient had advised for whole abdomen USG. USG finding was left ovarian endometrioma. Considering clinical features and USG finding , patient treated with TAB CystolibNutra 1 OD (Charakpharma), SYP. Amyron 2tsf BD, Panchsakar powder 5gm at night, Lavanbhaskar powder 3gm with Sankhbhasma $250 \mathrm{mg}$ BD and TAB Himcospaz 1 $\mathrm{BD}$ (Himalyapharma) .The above treatment continued for 3 months with 3 follow up in every month. In every follow up patient clinically improved. In last visit patient had advised lower abdomen USG. USG finding showed complete cure of left ovarian endometrioma (kaphaja cyst).

Copy Right, IJAR, 2017,. All rights reserved.

\section{Introduction:-}

Endometriosis is a benign estrogen dependent gynecological disease characterized by endometrial tissue located outside the uterus. The disease affects approximately 5-10\% of women of reproductive age in India. Approximately $17 \%$ of subfertile women have endometrioma, and it is estimated that $20-40 \%$ have endometriosis. Ovarian endometrioma a subtype of endometriosis affects $17-44 \%$ of women with endometriosis. Ovarian endometrioma is also known as chocolate cyst contain thick brown fluid . In 1957 Hughesdon suggested that endometrial implants, located on the surface of ovary are the cause of endometrioma. According to Hughesdon theory, menstrual shedding and the endometrial implant bleeding are trapped and cause a gradual invagination of the ovarian cortex. Ovarian endometriomais found to have similarity with the disease kaphajagranthi. Granthi is nothing but a pathological condition of doshas in muscular tissue ,blood, fat and structure of vessels which results into 
gland like abnormal growth or cyst or neoplasm. Patient had tried out allopathic treatment as suggested by allopathic gynecologist ,but had no relief. So she was given Ayurveda management. Patient was successfully managed with this without any side effect.

\section{Material and method:-}

Place of study:-

PrasutiTantraEvamStreeRog OPD, Gurukul Campus Hospital Uttrakhand Ayurveda University Haridwar.

\section{Case report:-}

The present case study is successful management of a case of left ovarian endometrioma (kaphajagranth). A 20 years old patient with registration number 1348/19340 came to PrasutiTantraEvamStreeRoga OPD, Gurukul Campus U. A. U. with chief complaints of moderate pain in whole abdomen, short cycle menses with prolong duration of bleeding , burning micturation, with whitish discharge $\mathrm{p} / \mathrm{v}$ and mild itching in lower abdomen .Associated symptom was constipation.

\section{History of present illness:-}

The patient was assymptomatic one and half year back. But since then patient has been suffering from whole abdomen pain, short cycle with prolong duration of bleeding, burning micturation, with whitish discharge and mild itching in lower abdomen.. Patient was psychologically upset since last six month. She had taken allopathic treatment, but did not get relief. Hence the patient came to PrasitiTantraEvamStreeRoga OPD Gurukul Campus U.A.U. Hospital.

Personal history:-

Table 1:-Personal history.

Menstrual history- Regular without pain ,normal color and consistency ,9-10 days bleeding after interval of 20-25 days.

\begin{tabular}{|l|l|l|}
\hline Name-xyz & Bala-madhyam & Prakriti -vatta pitta \\
\hline Age-20 years & Sleep- normal & b.p.- 120/80 \\
\hline Sex-female & Addiction- none & Weight-50 kg \\
\hline Marital status-unmarried & Bowel habit- constipation & Height $\mathbf{- 5}$ fit \\
\hline Occupation- student & Appetite- normal & \\
\hline
\end{tabular}

Table:2Ashtavidhapariksha

Nadi ( pulse rate)-80 per min.

Mala (stool)- constipation

Shabda (speech)-clear

Druka (eyes)-normal

Treatment plan- Patient was treated on OPD basis.
Mutra (urine)-burning

Jivha (tounge)- niram

Sparsha (touch)-normal

Akruti (built)-madhyam

A) Selected Ayurvedic drugs:

Table3:- Dose ,Route, Kala (drug administration time), Anupan

\begin{tabular}{|c|c|c|c|c|}
\hline Name of medicine & Dose & route & kala & anupana \\
\hline $\begin{array}{l}\text { 1.Tab.Cystolib } \\
\text { Nutra(charak) }\end{array}$ & 1 tab o.d. & oral & After meal & Luke warm water \\
\hline 2.Tab Posex fort(amil) & 2 tab b.d. & oral & $\begin{array}{r}\text { Only during cycle, } \\
\text { after meal }\end{array}$ & Luke warm water \\
\hline 3.Syp.Amyron(amil) & 2 tsfb.d. & oral & After meal & - \\
\hline 4..Tab.Himcospaz (himalya) & 1 b. d. & oral & After meal & Luke \\
\hline 5.Panchsakar powder & $3 \mathrm{gm}$ od & oral & $\begin{array}{r}\text { After meal at bed } \\
\text { time }\end{array}$ & Warm water \\
\hline $\begin{array}{rrr}\text { 6.Lavan } & \begin{array}{r}\text { bhaskar with } \\
\text { sankhbhasm }\end{array} \\
\end{array}$ & $\begin{array}{r}3 \mathrm{gm} \text { b.d. } \\
250 \mathrm{mg}\end{array}$ & oral & After meal & Warm water \\
\hline 7.Varun shigrukwath & $40 \mathrm{ml}$ b.d. & oral & After meal & - \\
\hline
\end{tabular}


Duration:-The above treatment continued for 3 months with monthly follow up.

Criteria for selection medicine:-

Medicine were selected on the basis of their properties useful in pacifiying vitiated doshas in kapajagranthi (ovarian endometrioma) and ability to relieve sign and symptoms of endometrioma.

Table 3:- Ingredients of medicine with their use.

\begin{tabular}{|c|c|c|}
\hline Name of medicine & $\begin{array}{r}\text { Ingredients } \\
\end{array}$ & Properties and use \\
\hline Tab Cystolibnutra & $\begin{array}{r}\text { Aloe barbadensis } 100 \mathrm{mg} \\
\text { Calcium carbonate } 100 \mathrm{mg} \\
\text { Magnesium oxide } 100 \mathrm{mg} \text { etc. }\end{array}$ & $\begin{array}{l}\text { Food for ovarian health } \\
\text { recommended for PCOS (poly } \\
\text { cystic ovarian syndrome) }\end{array}$ \\
\hline Tab Posex fort & Khadir ,lodhra .lajjalu etc. & $\begin{array}{cc}\text { Haemostyptic } & \begin{array}{r}\text { with astringent } \\
\text { checks bleeding, }\end{array}\end{array}$ \\
\hline SypAmyron & $\begin{array}{l}\text { Haritiki, } \\
\text {,punarnava,Ashwagandha ,shatavari } \\
\text { papaya etc. }\end{array}$ & $\begin{array}{l}\text { Rich source of Iron. } \\
\text { Anemia. }\end{array}$ \\
\hline Tab Himcospaz & Ajmoda, ginger,sati & $\begin{array}{l}\text { Antispasmodic. } \\
\text { Useful for spasmodic pain }\end{array}$ \\
\hline Pancsakar powder & Sunthi, swarnpatri,shatpuspha etc. & $\begin{array}{c}\text { Laxative } \\
\text { Useful for constipation }\end{array}$ \\
\hline $\begin{array}{r}\text { powderwith } \\
\text { Sankhbhasma }\end{array}$ & $\begin{array}{r}\text { Souvarchalalavana,vidalavana, } \\
\text { saindhavalanvana etc. }\end{array}$ & $\begin{array}{l}\text { Balance vata and kapha. } \\
\text { Useful in bloating, gas problem. } \\
\text { Sankhbhasma is anta acid,anti } \\
\text { spasmodic. }\end{array}$ \\
\hline Varunshigrukwath & Varun .shigru, punarnava etc. & $\begin{array}{l}\text { Diuretic. } \\
\text { Pacify vata and kapha. }\end{array}$ \\
\hline
\end{tabular}

Ahar and vihar (diet and mode of life) advised during treatment:-

Pathya(regime to be follow):-

All ruksha (dry),katu (bitter), and dipan things(appetizer) gugglu and shilajatu,yawa ,mudga ,patola ,twig of vettagra, adequate sleep at night, regular exercise. All these having kaphadosa pacifying properties.

Apathya (regime to be restricted):-

Use of edible made with milk and iksu, meat of aquatic animals, sweet, heavy ,and moisture producing substance, avoid day sleep. All these having kapha vitiating properties.

\section{Counseling:-}

As patient was also psycologically upset hence proper counseling of patient was done .She was made aware about hormonel changes in female body around this age .Patient was made confident that this condition is treatable.

\section{Follow up first:-}

After one month therapy Panchsakar powder and Lavanbhaskar with Sankhbhasma powder stopped. Remaining treatment continue as such for next one month.

\section{Duration:-}

The above treatment followed for next one month.

\section{Follow up second:-}

Signs and symptoms of patient regarding endometrioma were assessed during each follow up and result were drawn after last follow up.

The above treatment followed for last one month.

Grading Table 6:-Criteria for assessment of result.

\begin{tabular}{|l|r|r|r|r|}
\hline Signs $\begin{array}{r}\text { and } \\
\text { symptoms }\end{array}$ & normal & Mild(1) & Moderate(2) & Severe(3) \\
\hline Whole abdomen pain & 0 & 1 & 2 & 3 \\
\hline
\end{tabular}




\begin{tabular}{|c|c|c|c|c|}
\hline $\begin{array}{l}\text { Short cycle with } \\
\text { prolong bleeding } \mathrm{p} / \mathrm{v}\end{array}$ & 0 & 1 & 2 & 3 \\
\hline Burning urine & 0 & 1 & 2 & 3 \\
\hline Whitish discharge & 0 & 1 & 2 & 3 \\
\hline Loss of appetite & 0 & 1 & 2 & 3 \\
\hline $\begin{array}{l}\text { Mild itching in lower } \\
\text { abdomen }\end{array}$ & 0 & 1 & 2 & 3 \\
\hline
\end{tabular}

\section{Observation and result:-}

Table 7:- Change in signs and symptoms during each follow up.

\begin{tabular}{|r|r|r|r|r|}
\hline Signs $\begin{array}{r}\text { and } \\
\text { symptoms }\end{array}$ & Before treatment & First follow up & Second follow up & Third follow up \\
\hline Whole abdomen pain & 2 & 1 & 0 & 0 \\
\hline $\begin{array}{r}\text { Short cycle with } \\
\text { prolong bleeding p/v }\end{array}$ & 3 & 2 & 1 & 0 \\
\hline Burning urine & 3 & 2 & 1 & 0 \\
\hline Whitish discharge & 3 & 2 & 1 & 0 \\
\hline Loss of appetite & 2 & 0 & & 0 \\
\hline $\begin{array}{l}\text { Mild itching in lower } \\
\text { abdomen }\end{array}$ & 1 & 0 & 0 & \\
\hline
\end{tabular}

Table 7 shows that there is significantrlief in all sign and symptoms of endometrioma. It means that selected management of endometrioma is effective.

\section{Discussions:-}

In AyurvedicSamhitaGranthi and Arbuda description of female reproductive system is not available. AcharyaCarak has included these in the chapter dealing with Sotha (edema / inflammation ) due to similarity in basic clinical feature i.e. Sotha and Granthi or Arbuda. AcharyaCarak has clearly mentioned that Sothas are situated in different body parts, these are many in number due to difference in their location, clinical features names and types. This clearly indicates that basically etiopathogenesis, clinical features and treatment of Granthi and Arbuda of reproductive system are identical to the Granthi and Arbuda of any other part of the body, however few clinical features present due to specific location of disease. Due to intake of tridosas vitiating diet, vitiated vatta, pitta ,kapha vitiates mamsa, rakta, and medas mixed with kapha produce rounded, protuberant, knotty swelling. Since it is glandular, so it is called granthi or benign swelling or cyst.

Endometrioma is a benign estrogen dependent gynecological disease characterized by endometrial tissue located outside the uterus. Ovarian endometrioma also known as chocolate cyst contain thick brownish fluid, resemblance with kapajagranthi. Granthi means a cyst or cystic swelling. Cyst are sac like structure that can be filled with fluid,pus or other gaseous material. It is non cancerous or benign in nature. In Kaphajagranthi the granthi will be cold ,has body color , associated with itching and less pain, hard like stone, grows slow manner, when it breaks it discharge colored pus .Hence we can correlate ovarian endometrioma with kapajagranthi .In granthi, kapha is a predominant dosa and dusya is meda, mamsa having properties like kapha. The selected drugs have kapha pacifying properties. Charakpharma preparation Tab CystolibNutra recommended for cystic growth of ovary as endometrioma or poly cystic ovarian syndrome. Other drugs are selected according to symptoms. The above treatment continued for three months with monthly follow up. During complete duration of treatment, patient was instructed to follow pathya and apathy as advised. After three month treatment patient examined and it was found patient was completely cured symptomatically. USG finding showed there was absent of ovaianendometrioma or kaphajagranthi.

This shows that if plan of treatment is selected according to principles of Ayurveda along with proper drug, dose, duration , anupana ,pathya and apathya there is assurance of success in treatment as seen in this case.

\section{Conclusion:-}

Hence it is concluded that above treatment is highly effective in the management of Ovarianendometrioma or kaphajagranthi. 


\section{References:-}

1. Prof. PremVatiTiwari -AyurvedicPrasutiTantraEvamStreeRroga -second part -Chaukmbha publication ,chapter 7,page no.357, 358,359,365,386.

2. Endometriosis :Management of ovrianendometriomas. Author: Barbara S Levy

3. SushrutaSamhita:first part by Dr. Ambikaduttshastri, chaukambha publication, nidansthana eleventh chapter page no.270, 271.

4. Caraksamhita :second part by Dr.Yadunandanupadhyay, chikitsasthana chapter 12, page no.

5. Jeffcoates Principles of gynaecology International edition, chapter $19^{\text {th }}$ page 357 . 